\title{
SHORT-TERM EFFECTS OF WILDFIRE ON MONTANE STREAM ECOSYSTEMS IN THE SOUTHERN ROCKY MOUNTAINS: ONE AND TWO YEARS POST-BURN
}

\author{
Sharon J. Hall ${ }^{1}$ and Danica Lombardozzi ${ }^{2}$
}

\begin{abstract}
The frequency and intensity of wildfire in the western United States has increased over the last century, creating a heterogeneous mosaic of landscapes in various stages of recovery. The 2002 Hayman Fire was one of the largest wildfires in Colorado history and was unprecedented for its speed and intensity, with over 50\%-70\% of the burn area classified as moderate to high severity where much of the canopy crown was consumed. We evaluated the shortterm impact of the Hayman Fire on ecological properties in montane stream ecosystems in the summers of 2003 and 2004 , one and two years post-fire. Fire significantly altered surface temperature, dissolved oxygen concentration, and the chemical composition of stream water, including concentrations of nitrate, phosphate, and mineral salts. However, fire did not have significant impacts on stream conductivity, $\mathrm{pH}$, or total concentrations of cations or anions during our study period. Streams in the burn area contained fewer benthic macroinvertebrate taxa compared to unburned streams during the year after fire and contained lower invertebrate densities and biomass compared to reference streams 2 years post-fire. Average C:N ratio of the benthic macroinvertebrate community was significantly and negatively related to stream nitrate concentration, possibly due to a shift in community composition or invertebrate nitrogen acquisition in fire-affected streams.
\end{abstract}

Key words: benthic macroinvertebrate, Hayman Fire, mixed coniferous forest, Rocky Mountains, stoichiometry, C:N.

Decades of fire suppression combined with drought, early snowmelt, and expansion of the urban wildland interface have increased the frequency and intensity of large fires in the western United States (Keeley et al. 1999, Veblen et al. 2000, Schoennagel et al. 2004, Westerling et al. 2006). Fire rapidly consumes plant biomass and generally accelerates nutrient return to soils in the short term (Covington and Sackett 1992), but other ecological effects are highly variable depending on a suite of factors, including burn characteristics (intensity, severity, and area burned), post-fire climatic patterns (timing, duration, and magnitude of precipitation and/or spring runoff), recovery efforts, and the abiotic and biotic characteristics of ecosystems that drive heterogeneity (Johnson 2001). Thus, assessment of the impact of fire requires an understanding of local site characteristics interpreted in the context of conceptual frameworks of post-fire recovery patterns that have been developed across a range of different ecosystems and events (Minshall 2003).

Streams and riparian corridors within the semiarid, southern Rocky Mountains are important habitats for aquatic and terrestrial biota and provide key ecosystem services to humans, including water provisioning, enhanced water quality, and recreation (Daily et al. 1993, Naiman and Decamps 1997, Wilson and Carpenter 1999). The direct effects of fire on stream ecosystems, such as atmospheric inputs or excessive heating, are relatively rare and, when they occur, have short-lived consequences for ecological processes (Minshall 2003). More persistent are the indirect effects of fire, including modification of channel morphology and hydrology, that often occur during large precipitation events following the summer fire season (Gresswell 1999). Fires that char or consume the forest floor can significantly alter water movement and erosion within catchments, increasing overland flow and sediment transport to aquatic ecosystems and causing complex changes in community and trophic structure (Rinne 1996). Furthermore, nutrients, organic compounds, and soil contaminants become concentrated after fire and often bind to fine sediments, increasing their transport and exposure to fish and aquatic invertebrate communities that live in interstitial spaces within stream benthos (Malmon et al. 2007). Benthic macroinvertebrates are important components

\footnotetext{
${ }^{1}$ Arizona State University, School of Life Sciences, Box 874501, Tempe, AZ 85287-4501. Email: sharonjhall@asu.edu

${ }^{2}$ Cornell University, Department of Ecology and Evolutionary Biology, E145 Corson Hall, Ithaca, NY 14853.
} 
TABLE 1. Characteristics of streams sampled in 2003 ( 1 year post-burn) and 2004 (2 years post-burn).

\begin{tabular}{|c|c|c|c|c|c|c|}
\hline Category & Stream & $\begin{array}{l}\text { Stream } \\
\text { order }\end{array}$ & Elevation $(\mathrm{m})$ & $\begin{array}{l}\text { Discharge } \\
\left(\mathrm{m}^{3} \cdot \mathrm{s}^{-1}\right)\end{array}$ & $\begin{array}{c}\text { Stream } \\
\text { width }(\mathrm{m})\end{array}$ & $\begin{array}{c}\text { Maximum stream } \\
\text { depth }(\mathrm{m})\end{array}$ \\
\hline \multicolumn{7}{|l|}{2003} \\
\hline Unburned & Upper Goose Creek & 2 & 2560 & 0.76 & 9.3 & 0.6 \\
\hline Burned & Lower Goose Creek & 2 & 2316 & 0.78 & 13.0 & 0.5 \\
\hline Unburned & Upper Wigwam Creek & 2 & 2651 & 0.14 & 2.0 & 0.3 \\
\hline Burned & Lower Wigwam Creek & 2 & 2316 & 0.05 & 2.0 & 0.1 \\
\hline Unburned & Upper West Creek & 3 & 2499 & 0.04 & 1.5 & 0.1 \\
\hline Burned & Lower West Creek & 3 & 2377 & 0.10 & 1.5 & 0.1 \\
\hline \multicolumn{7}{|l|}{2004} \\
\hline Reference & Jackson Creek & 1 & 2499 & 0.43 & 0.8 & 0.2 \\
\hline Reference & Sugar Creek & 2 & 1991 & 0.31 & 1.8 & 0.1 \\
\hline Reference & West Creek & 3 & 2499 & 0.42 & 2.6 & 0.1 \\
\hline Reference & Pine Creek & 2 & 2133 & 0.19 & 1.1 & 0.2 \\
\hline Reference & Freeman Creek & 1 & 2316 & 1.42 & 4.6 & 0.3 \\
\hline Burned & Crystal Creek & 1 & 2560 & 0.10 & 1.3 & 0.1 \\
\hline Burned & Wigwam Creek & 2 & 2316 & 0.33 & 3.4 & 0.2 \\
\hline Burned & Trail Creek & 1 & 2357 & 0.25 & 1.4 & 0.2 \\
\hline Burned & Cabin Creek & 2 & 2255 & 0.09 & 0.8 & 0.1 \\
\hline Burned & Goose Creek & 2 & 2381 & 2.80 & 7.9 & 0.4 \\
\hline
\end{tabular}

of food webs, and as consumers of detritus, they play a key role in the stoichiometric composition of material exported from watersheds (Grimm 1988). Increased inputs of nutrients, light, or ash following fire can alter competitive interactions and thus change the composition and stoichiometry of invertebrate communities (Cross et al. 2003).

Following 2 years of severe drought, in June 2002 the Hayman Fire burned $560 \mathrm{~km}^{2}$ of montane forest in the Pike-San Isabel National Forest, $50 \mathrm{~km}$ southwest of Denver, Colorado, and became one of the largest wildfires in Colorado history (Graham 2003). As is common with wildfire, the Hayman Fire created a mosaic of landscapes of varying burn intensities (Fig. 1). However, unprecedented in the historical record of the area was the size and homogeneity of stand-replacing burned patches, with $50 \%-70 \%$ of the affected area classified as moderate or high severity (litter and fine woody debris consumed, lethal temperatures to $5 \mathrm{~cm}$ or deeper in the soil). Riparian areas within the region were also heterogeneously affected, with $20 \%-95 \%$ of individual streams classified as moderately to severely burned (Kershner et al. 2003). Furthermore, intensity, extent, and timing of the fire just before the summer rainy season led to widespread use of fire retardants containing fertilizers and other compounds (e.g., Fire-Trol ${ }^{\circledR}$ ) and extensive post-fire rehabilitation, including straw mulching and aerial seeding with annual grasses in order to pre- vent severe erosion (Robichaud et al. 2003, Romme et al. 2003b, Lewis et al. 2006).

To date, only a few studies have evaluated the effects of the Hayman Fire on ecological processes, and all were conducted immediately after the burn (case study reports in Graham 2003: Chong et al. 2003, Cipra et al. 2003, Kershner et al. 2003, Kotliar et al. 2003, Robichaud et al. 2003, Romme et al. 2003a, 2003b). In order to increase our understanding of post-fire recovery patterns, we evaluated stream chemistry, benthic macroinvertebrate densities, and invertebrate community tissue ratios of carbon $(\mathrm{C})$ and nitrogen $(\mathrm{N})$ in small 1st- to 3rd-order streams within and outside of the Hayman burn area during the summers of 2003 and 2004, one and two years after the fire. We expected that the Hayman Fire and subsequent recovery efforts would increase nutrient and sediment loading to streams within the first 2 years post-fire. Furthermore, we expected that the fire would alter the C:N ratio of the benthic macroinvertebrate community through changes in community composition or through community assimilation of nitrogen released from fire or flooding.

\section{Methods}

\section{Site Selection and Description}

During July 2003 (1 year post-burn), we sampled stream chemistry and benthic macroinvertebrates in 3 streams with unburned 


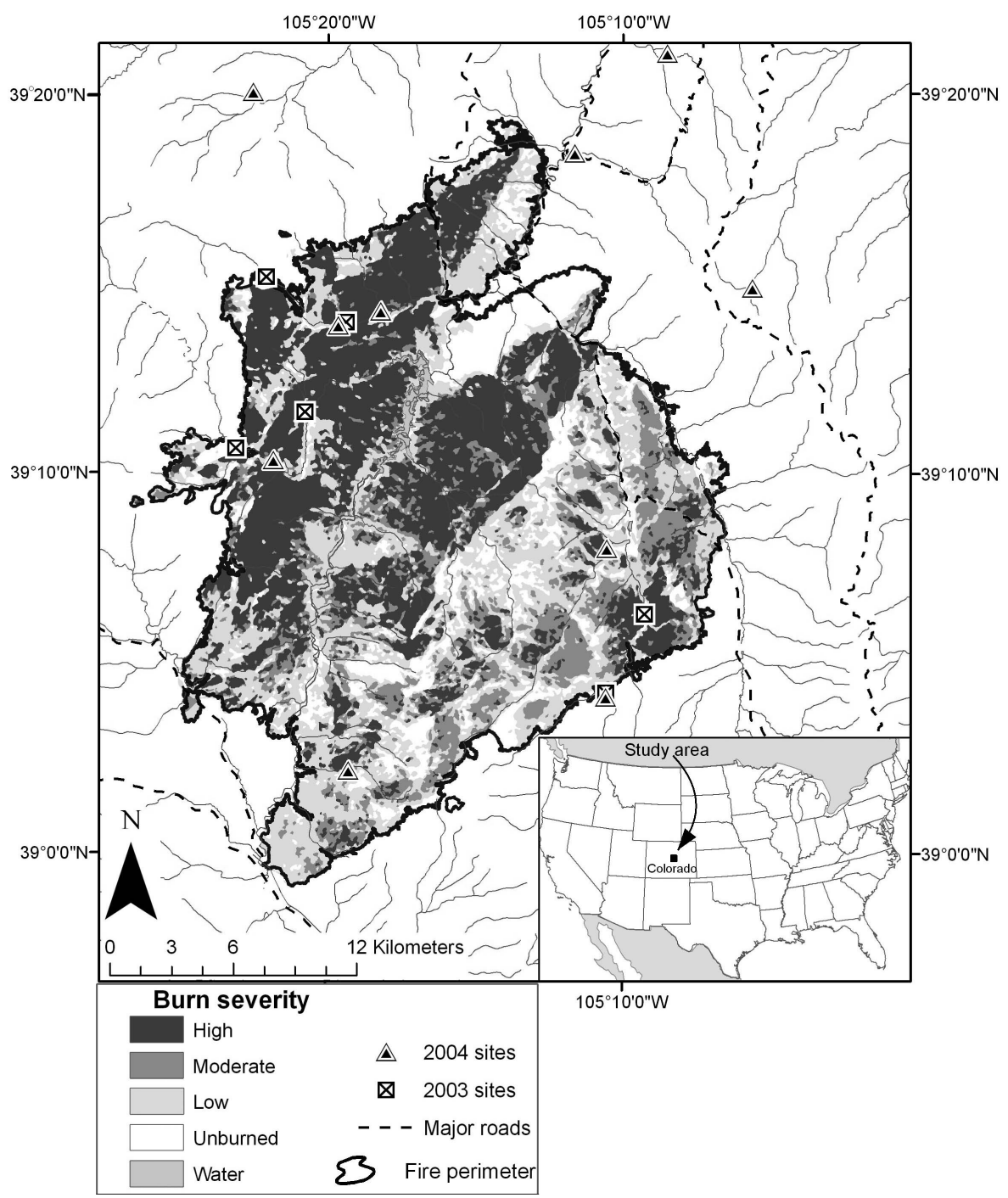

Fig. 1. Location of sites within the Hayman burn area, Pike-San Isabel National Forest, Colorado. Sites sampled in 2003 (paired) are indicated with an X; sites sampled in 2004 (not paired) are indicated with a black triangle. Burn severity is indicated by color. Burn severity data from the NPS-USGS National Burn Severity Mapping Project, http://burnseverity .cr.usgs.gov/show_fire.php?intID=55”

upper catchments but downstream reaches that crossed into the Hayman burn area $(n=3$ paired streams; Fig. 1, Table 1). While a paired design controls for inherent differences between individual streams, conclusions are limited by confounding factors associated with natural, longitudinal changes in stream characteristics over long distances. To minimize these limitations, we selected paired sites according to 7 criteria: paired sites were similar with respect to geology (Pikes Peak granite), stream order (2nd or 3rd order, equivalent within pairs), slope $\left(<2^{\circ}, \leq 1^{\circ}\right.$ difference between pairs), elevation (<300 m [1000 ft] difference between pairs, approximately), and vegetation (see below); paired sites experienced minimal upstream agricultural land use; and paired sites were as close to each other as possible within constraints of road closures and accessibility. Minor tributaries (Hankins Gulch and Manchester Creek) of 2 of the 3 streams between upper and lower reaches were judged 
inconsequential during our sampling period $\left(<0.001 \mathrm{~m}^{3} \cdot \mathrm{s}^{-1}\right)$. Elevation of unburned sites ranged from 2499 to $2651 \mathrm{~m}$ and elevation of burned sites ranged from 2316 to $2377 \mathrm{~m}$. Vegetation in the Hayman burn area is dominated by Pinus ponderosa (ponderosa pine), Pseudotsuga menziesii (Douglas-fir), and Populus tremuloides (quaking aspen). Riparian areas are dominated by Salix spp. (willow), Populus angustifolia (narrowleaf cottonwood), Populus deltoides (eastern cottonwood), various graminoids, and forbs.

Due to extensive road closure in the burn area that restricted access to streams that met our criteria, in 2004 we altered our approach to a nonpaired (independent) design to increase the statistical power of our study. In July 2004 ( 2 years post-burn), we sampled from 5 intact streams that were not burned (reference) and 5 streams within the burn area $(n=5$; Fig. 1 , Table 1).

Streams were selected according to criteria similar to those used in 2003: they were all relatively small (1st to 3rd order), low gradient $\left(<2^{\circ}\right.$ slope $)$, underlain by Pikes Peak granite, and similar in vegetation over the reaches sampled (ponderosa pine / Douglas-fir overstory, willow/cottonwood riparian community), and all experienced minimal upstream agricultural land use (Table 1). Elevation of reference sites ranged from 1991 to $2499 \mathrm{~m}$, and elevation of burned sites ranged from 2255 to $2560 \mathrm{~m}$.

\section{Sample Collection}

In 2003 a 10-m reach of stream at each site was selected for sampling. Ten water samples, equally spaced to span the width of the channel, were collected in acid-washed bottles at mid-depth. Handheld bottle samplers were used because streams were shallow $(0.1-0.6 \mathrm{~m}$ depth) and well mixed. Additionally, at 3 subsites along the $10-\mathrm{m}$ reach $(1,5$, and $10 \mathrm{~m})$, we measured a suite of stream properties, including stream channel characteristics (width, channel depth at 0.5-m intervals across the stream) and discharge (Swoffer Model 3000 flow meter). Additionally, we measured chemical properties of stream water at mid-depth, including dissolved oxygen (YSI 550 DO meter, YSI, Inc.), conductivity, and pH (YSI 63 handheld $\mathrm{pH}$ and conductivity meter). Field instruments were calibrated prior to each use. Invertebrates were sampled using a
Surber sampler (355- $\mu \mathrm{m}$ mesh) with a 930.2$\mathrm{cm}^{2}$ sampling area. The sampling location was approached from downstream, and the sampler was placed in position as quickly as possible. Each of the larger rocks within the perimeter of the frame was washed by hand at the mouth of the sampler and removed. The remaining substrate was disturbed to a depth of $15 \mathrm{~cm}$ for 1 minute using a metal spike. The contents that washed into the net were transferred into a large container, the larger rocks were handrinsed and removed, and the organic material was further separated from fine sediment using another filter of the same mesh size.

In 2004 we expanded our sampling area to a 60-m stretch of stream to characterize stream properties at a larger scale. Three subsites were identified at 20,40, and $60 \mathrm{~m}$ on each stream. At each subsite, 3 water samples, equally spaced across the stream, were collected at mid-depth. As in 2003, handheld bottle samplers were used because streams were shallow (0.1-0.4 m depth) and well mixed. Three samples per stream (consisting of 3 subsamples each) were analyzed independently and averaged for each site. Additionally, at each subsite we sampled benthic macroinvertebrates and chemical properties, and we measured stream characteristics according to the methods described above. All stream water and invertebrate samples were transferred on ice to the laboratory at Colorado College and stored at $4{ }^{\circ} \mathrm{C}$ until analyses were performed. Field sampling during both years occurred in the mornings between 9:00 and 12:00.

\section{Laboratory Analyses}

Within 48 hours of collection, invertebrates were separated from organic matter/sediment, counted, and identified to order or family (for Chironomidae only). Each sample was examined twice for accuracy in 2004. Identified invertebrates were rinsed in deionized water, placed by order into 1-6 preweighed tin capsules (depending on availability), dried at $70^{\circ} \mathrm{C}$ for 24 hours, reweighed, and combusted for total C and $\mathrm{N}$ on a Carlo Erba CHN analyzer (CE Elantech, Lakewood, NJ) calibrated internally with homogenized atropine and externally with peach leaves (Thermo Fisher Scientific Inc., www.thermofisher.com; Stelzer and Lamberti 2002). If available, the remaining individuals that were not used for $\mathrm{C}$ and $\mathrm{N}$ analyses were placed on a preweighed filter and dried 
TABle 2. Properties of 3 streams outside of (unburned) and within (burned) the Hayman Fire area, summer 2003 (1 year post-burn). $P$-values indicating statistical significance $(\alpha=0.10)$ are bolded.

\begin{tabular}{|c|c|c|c|c|c|c|c|}
\hline & \multicolumn{2}{|c|}{ Goose Creek } & \multicolumn{2}{|c|}{ West Creek } & \multicolumn{2}{|c|}{ Wigwam Creek } & \multirow[b]{2}{*}{$P$-value } \\
\hline & Unburned & Burned & Unburned & Burned & Unburned & Burned & \\
\hline \multicolumn{8}{|l|}{ Stream properties } \\
\hline Surface temp. $\left({ }^{\circ} \mathrm{C}\right)$ & 12.9 & 14.7 & 17.5 & 21.0 & 11.9 & 16.8 & 0.06 \\
\hline $\mathrm{pH}$ & 7.7 & 7.4 & 8.3 & 7.8 & 7.1 & 8.1 & 0.94 \\
\hline Conductivity $\left(\mu \mathrm{S} \cdot \mathrm{L}^{-1}\right)$ & 33.5 & 40.5 & 128.8 & 210.5 & 33.8 & 93.3 & 0.16 \\
\hline $\mathrm{DO}\left(\mathrm{mg} \cdot \mathrm{L}^{-1}\right)$ & 8.4 & 7.7 & 7.2 & 6.7 & 8.3 & 7.6 & 0.01 \\
\hline DO (\% saturation) & 78.7 & 75.5 & 75.2 & 75.9 & 76.0 & 77.8 & 0.89 \\
\hline \multicolumn{8}{|l|}{ Stream chemistry $\left(\mathrm{mg} \cdot \mathrm{L}^{-1}\right)$} \\
\hline $\mathrm{Li}^{+}$ & 0.02 & 0.09 & 0.05 & 0.00 & 0.01 & 0.00 & 0.93 \\
\hline $\mathrm{Na}^{+}$ & 2.94 & 3.41 & 6.74 & 7.36 & 2.73 & 3.73 & 0.05 \\
\hline $\mathrm{K}^{+}$ & 0.73 & 0.97 & 1.92 & 2.60 & 0.87 & 2.04 & 0.12 \\
\hline $\mathrm{Mg}^{2+}$ & 0.81 & 0.96 & 2.53 & 4.07 & 0.62 & 1.71 & 0.15 \\
\hline $\mathrm{Ca}^{2+}$ & 5.23 & 6.62 & 21.57 & 33.85 & 5.28 & 16.31 & 0.14 \\
\hline $\mathrm{F}^{-}$ & 1.22 & 1.36 & 1.87 & 1.93 & 2.10 & 2.29 & 0.08 \\
\hline $\mathrm{Cl}^{-}$ & 0.38 & 0.64 & 1.39 & 1.64 & 0.27 & 0.60 & 0.01 \\
\hline $\mathrm{NO}_{3}^{-}$ & 0.25 & 0.34 & 0.00 & 0.32 & 0.25 & 0.57 & 0.09 \\
\hline $\mathrm{PO}_{4}^{3-}$ & 0.00 & 0.00 & 0.06 & 0.25 & 0.00 & 0.27 & 0.20 \\
\hline $\mathrm{SO}_{4}{ }^{2-}$ & 4.22 & 4.90 & 3.13 & 2.60 & 3.77 & 6.31 & 0.42 \\
\hline \multicolumn{8}{|c|}{ Density of benthic invertebrates (individuals $\cdot \mathrm{m}^{-2}$ ) } \\
\hline Ephemeroptera & 218.6 & 161.3 & 358.3 & 50.2 & 53.8 & 96.8 & 0.41 \\
\hline Plecoptera & 68.1 & 0 & 78.8 & 3.6 & 125.4 & 225.8 & 0.83 \\
\hline Diptera & 261.6 & 505.3 & 243.7 & 100.3 & 197.1 & 831.4 & 0.39 \\
\hline Coleoptera & 14.3 & 0 & 0 & 0 & 93.2 & 10.8 & 0.33 \\
\hline Trichoptera & 0 & 0 & 164.8 & 0 & 3.6 & 0 & 0.41 \\
\hline Hemiptera & 0 & 0 & 0 & 0 & 3.6 & 0 & 0.42 \\
\hline Hydracarina & 14.3 & 0 & 32.3 & 0 & 78.8 & 0 & 0.16 \\
\hline Isopoda & 0 & 0 & 25.1 & 0 & 0 & 0 & 0.42 \\
\hline Oligochaeta & 0 & 103.9 & 39.4 & 0 & 3.6 & 0 & 0.68 \\
\hline Molluses & 0 & 0 & 7.2 & 0 & 0 & 0 & 0.42 \\
\hline Hirudinea & 0 & 0 & 3.6 & 0 & 0 & 0 & 0.42 \\
\hline ORDERS REPRESENTED & 5 & 3 & 9 & 3 & 8 & 4 & 0.07 \\
\hline
\end{tabular}

at $70{ }^{\circ} \mathrm{C}$ for 24 hours. The sum of the dry weights were used to determine total biomass. Stream water samples were filtered using glass-fiber filters and analyzed within 24-48 hours of collection for total anions $\left(\mathrm{F}^{-}, \mathrm{Cl}^{-}\right.$, $\left.\mathrm{Br}^{-}, \mathrm{NO}_{2}^{-}, \mathrm{NO}_{3}^{-}, \mathrm{PO}_{4}{ }^{3-}, \mathrm{SO}_{4}{ }^{2-}\right)$ and cations $\left(\mathrm{Na}^{+}, \mathrm{Ca}^{2+}, \mathrm{Li}^{+}, \mathrm{K}^{+}, \mathrm{NH}_{4}^{+}, \mathrm{Mg}^{2+}\right)$ on a Dionex DX-500 ion chromatograph (Dionex Corporation, Sunnyvale, CA).

We used a standard curve to calibrate the ion chromatograph, and we used blanks and check standards to test for instrument drift.

\section{Statistical Analyses}

We used SPSS 11.0 software (SPSS 2005) to perform all statistical tests. Stream chemistry, stream properties, and characteristics of benthic macroinvertebrates were analyzed for the effects of fire using Student's paired $t$ tests (for 2003) or $t$ tests (for 2004). Data that did not conform to model assumptions were transformed prior to analyses $(\log 10)$ or analyzed using nonparametric Mann-Whitney $U$ tests if normality could not be achieved. The relationship between stream water nitrate $\left(\mathrm{NO}_{3}{ }^{-}\right)$concentration and invertebrate community C:N ratio was analyzed using least-squares regression. Because restricted access into the burn area limited the number of acceptable streams for the year after the fire $(n=3)$, we considered $P$-values $\leq 0.10$ significant for data from 2003. Two years post-burn, a larger sample size clarified the ecological effects of the fire $(n=5)$; thus $P$ values $\leq 0.05$ were considered significant for data from 2004.

\section{RESULTS}

The chemistry of small, mountain streams was significantly altered over the 2-year period after the Hayman Fire (Tables 2, 3). In particular, streams within the fire boundary contained more mineral salts $\left(\mathrm{Na}^{+}, \mathrm{Cl}^{-}, \mathrm{F}^{-}\right)$and $30 \%$ to $>100 \%$ higher concentrations of $\mathrm{NO}_{3}^{-}$in 
Table 3. Properties and chemistry of streams outside of (reference) and inside of (burned) the Hayman Fire area in summer 2004 ( 2 years post-burn). Mean $\left(s_{\bar{x}}\right) ; n=5$ streams per category. $P$-values indicating statistical significance $(\alpha=$ $0.05)$ are bolded.

\begin{tabular}{|c|c|c|c|}
\hline & Reference & Burned & $P$-value \\
\hline \multicolumn{4}{|l|}{ Stream properties } \\
\hline Surface temp. $\left({ }^{\circ} \mathrm{C}\right)$ & $12.4(1.5)$ & $10.8(0.8)$ & 0.39 \\
\hline $\mathrm{pH}$ & $7.5(0.3)$ & $7.6(0.2)$ & 0.74 \\
\hline Conductivity $\left(\mu \mathrm{S} \cdot \mathrm{L}^{-1}\right)$ & $77.7(17.7)$ & $107.6(25.5)$ & 0.36 \\
\hline $\mathrm{DO}\left(\mathrm{mg} \cdot \mathrm{L}^{-1}\right)$ & $5.1(0.8)$ & $4.9(0.2)$ & 0.80 \\
\hline DO (\% saturation) & $47.8(7.4)$ & $50.4(7.5)$ & 0.81 \\
\hline \multicolumn{4}{|l|}{ Stream chemistry $\left(\mathrm{mg} \cdot \mathrm{L}^{-1}\right)$} \\
\hline $\mathrm{F}^{-}$ & $1.8(0.2)$ & $2.4(0.5)$ & $0.29^{a}$ \\
\hline $\mathrm{Cl}^{-}$ & $2.3(1.0)$ & $1.3(0.3)$ & $0.46^{\mathrm{a}}$ \\
\hline $\mathrm{NO}_{2}^{-}$ & $0(0)$ & $0(0)$ & - \\
\hline $\mathrm{Br}^{-}$ & $0(0)$ & $0.7(0.4)$ & $0.01^{\mathrm{a}}$ \\
\hline $\mathrm{NO}_{3}^{-}$ & $0.5(0.1)$ & $1.2(0.5)$ & $0.42^{\mathrm{a}}$ \\
\hline $\mathrm{PO}_{4}^{3-}$ & $0(0)$ & $0.4(0.2)$ & $0.05^{\mathrm{b}}$ \\
\hline $\mathrm{SO}_{4}^{2-}$ & $5.6(1.4)$ & $7.4(1.2)$ & $0.26^{\mathrm{a}}$ \\
\hline $\mathrm{Li}^{+}$ & $0(0)$ & $0(0)$ & $0.70^{\mathrm{a}}$ \\
\hline $\mathrm{Na}^{+}$ & $4.9(0.8)$ & $5.3(1.1)$ & $0.93^{\mathrm{a}}$ \\
\hline $\mathrm{NH}_{4}^{+}$ & $0(0)$ & $0(0)$ & - \\
\hline $\mathrm{K}^{+}$ & $1.5(0.3)$ & $1.9(0.5)$ & $0.70^{\mathrm{a}}$ \\
\hline $\mathrm{Mg}^{2+}$ & $2.2(0.6)$ & $2.4(0.7)$ & $0.96^{\mathrm{a}}$ \\
\hline $\mathrm{Ca}^{2+}$ & $13.8(3.0)$ & $18.3(5.6)$ & $0.75^{\mathrm{a}}$ \\
\hline
\end{tabular}

aData were log-transformed $\left(\log _{10}[\mathrm{x}+0.01]\right)$ to satisfy model assumptions before statistical analyses.

bData analyzed using nonparametric Mann-Whitney U test.

a.

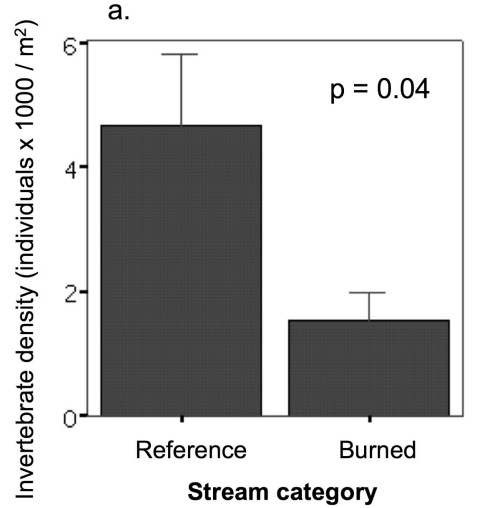

b.

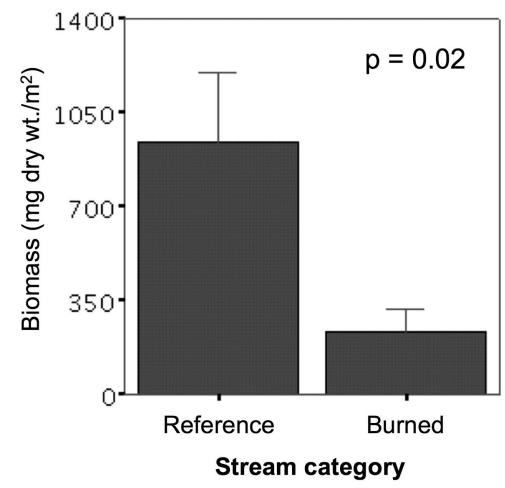

Fig. 2. Density (individuals $\cdot 1000 \mathrm{~m}^{-2}$ ) and biomass $\left(\mathrm{mg}\right.$ dry weight $\cdot \mathrm{m}^{-2}$ ) of benthic macroinvertebrates in reference and fire-affected streams 2 years after fire (summer 2004). Error bars represent one standard error and, and $n=5$ streams per category. Data were log-transformed prior to statistical analyses.

2003, and elevated levels of orthophosphate $\left(\mathrm{PO}_{4}{ }^{3-}\right)$ in 2004. Conductivity was always higher in burned streams compared to reference streams, but the differences were not statistically significant. The $\mathrm{pH}$ of stream water was not significantly affected by the fire in either year. In 2003, surface water was warmer for burned streams than for unburned streams when sampling was paired within individual streams (Table 2), but high variability between different sites in 2004 prevented detection of this pattern across the landscape in this year. Dissolved oxygen $\left(\mathrm{O}_{2}\right)$ concentrations $\left(\mathrm{mg} \cdot \mathrm{L}^{-1}\right)$ were significantly lower in streams draining burned catchments in 2003 compared to unburned catchments, but due to warmer stream temperatures in the burn area, fire did not significantly affect percent $\mathrm{O}_{2}$ saturation (Tables $2,3)$.

Similarly, fire significantly affected stream biological communities. Streams that drained burned catchments contained significantly 
fewer taxa in 2003, although there was no significant effect of the fire on any single taxon alone (Table 2). However, 2 years post-fire, streams in the burn area contained individuals from all taxa found in reference streams but contained significantly fewer individuals and lower biomass in 3 invertebrate orders (Diptera, Coleoptera, and Trichopera; Table 4). Moreover, total density and biomass of all benthic macroinvertebrates in the burn area were $60 \%$ and $80 \%$ lower, respectively, than in reference streams (Fig. 2).

Wildfire significantly altered $\mathrm{N}$ content of coleopterans, increasing body concentrations from $9.7 \%$ to $11.2 \% \mathrm{~N}$, but had no effect on individuals from other orders (Table 4). When averaged across all taxa and streams, the C:N ratio of benthic invertebrate tissue was negatively correlated to stream water $\mathrm{NO}_{3}{ }^{-}$concentration (least-squares regression: $n=10 ; y$ $\left.=-0.21 x+5.02 ; r^{2}=0.68 ; P=0.002\right)$.

\section{Discussion}

Stream ecosystems are highly individualistic in their responses to fire, depending in large part on burn severity, which modifies soil physical and hydrologic properties within affected watersheds (Minshall 2003, Malmon et al. 2007). For example, prescribed burns or lowintensity fires have minimal effects on stream chemistry or invertebrate communities, with slight increases in nutrient concentrations within days after burning but limited effects during base flow in the year following fire (Spencer et al. 2003, Stephens et al. 2004, Beche et al. 2005, Elliott and Vose 2005). Ecological responses after moderate- to highintensity burns are more variable, however, due to increasing heterogeneity of patches and likelihood of event-driven geomorphic changes. Some streams return to baseline conditions within weeks, even after significant inputs of ash or chemical retardants (Boulton et al. 2003, Earl and Blinn 2003), some return after 1-2 years (Vila-Escale et al. 2007), and others still show effects within invertebrate communities up to 10 years after stand-replacing burns (Minshall et al. 2001b).

Although streams draining burned catchments in this study were also variable in their responses, the severity of the Hayman Fire was reflected in significantly decreased invertebrate density and biomass, and elevated 
concentrations of nutrient solutes even after 2 years of recovery. However, the impacts on ecological properties were not catastrophic: 2 years after the fire, individuals in all of the 9 macroinvertebrate taxa identified within reference streams were represented within the burn area; stream temperatures and dissolved oxygen concentrations were not altered at a landscape scale in year 2; conductivity and $\mathrm{pH}$ were statistically unaffected in either year; and there were few changes in $\mathrm{N}$ content of individuals within the invertebrate community. Furthermore, invertebrate biomass and density of both reference and fire-affected streams were within the range of variability of other stand-replacing fires in the Intermountain West (Minshall et al. 2001a, 2001b), suggesting that these ecosystems fall within an expected trajectory of succession and may take at least a decade to reach complete recovery comparable to reference conditions.

Despite the severity of the burn for soil characteristics and vegetation structure (Lewis et al. 2006), climate factors likely played important roles in minimizing other short-term post-fire impacts. For example, in the latesummer monsoon months immediately after the fire in 2002 and again the following summer in 2003, rainfall in the Hayman area was 50\% of the long-term average (average of $6.4 \mathrm{~cm}$ precipitation in June/July 2002/2003 at Cheesman Lake, compared to an average of $13.5 \mathrm{~cm}$ precipitation for 1961-1990; Western Regional Climate Center 2007). These low rates of rainfall in the years following the fire likely limited projected rates of soil erosion and channel modification (Cipra et al. 2003). Sediment transport was also low during the winter following the fire, because the water-repellency of the upper soil layer decreased when the soil was wet with low intensity rain events and because snowmelt slowly infiltrated through the soil rather than generating overland flow events (Cipra et al. 2003). Although channel modification is expected to continue, erosion will likely slow considerably within the first 5 years post-fire as vegetation and soil organic matter reestablish in upland and riparian areas (Cipra et al. 2003, Beche et al. 2005).

Concentration of $\mathrm{NO}_{3}{ }^{-}$in stream water was significantly higher in burned compared to unburned reaches one year post-fire when streams were paired, but this difference disappeared when stream chemistry was consid- ered at a landscape scale in year 2. Similarly, except for in Coleoptera, there were few differences in concentrations of $\mathrm{C}$ or $\mathrm{N}$ in invertebrate tissue between burned and reference streams. The absence of a pattern in invertebrate nutrient concentrations may be due to insufficient taxonomic resolution (as orders often exhibit diverse feeding strategies); however, it may also reflect insignificant changes in $\mathrm{N}$ availability for consumers after fire. The stoichiometric composition of $\mathrm{C}, \mathrm{N}$, and phosphorus in aquatic organisms is thought to reflect the availability of limiting nutrients or the quality and abundance of food resources (Frost et al. 2002). Furthermore, streams draining burned ecosystems support increased populations of trophic generalists that rely more on autochthonous than allochthonous resources when input from streamside vegetation is reduced (Mihuc and Minshall 2005). Periphyton quality or quantity may not be significantly altered 2 years after burning in the watersheds studied. On the other hand, invertebrate community composition after fire may comprise taxa whose elemental composition is relatively homeostatic, as several studies have suggested that some taxa may be more plastic than others in responding to alterations in food quality or environmental conditions (Cross et al. 2003).

Despite the lack of differences observed in $\mathrm{N}$ concentrations in the benthic invertebrate community between unburned and reference streams, we found that average tissue $\mathrm{C}: \mathrm{N}$ of all invertebrates was significantly correlated to stream $\mathrm{NO}_{3}{ }^{-}$concentration, in part due to the low C:N ratio of the few taxa remaining in streams in the burn area. Large post-fire loads of soluble $\mathrm{NO}_{3}-$ may co-occur with shifts in invertebrate community composition and stoichiometry with no causal relationship between these trends because other independent factors are potentially modified by fire, such as sediment and solute transport from burned upland soils. Alternatively, high $\mathrm{NO}_{3}{ }^{-}$concentrations after fire may alter the competitive balance of benthic organisms, thus selecting for those fast-growing species with higher $\mathrm{N}$ requirements (Sterner and Elser 2002).

\section{Conclusion}

While large but not unprecedented in size, the 2002 Hayman Fire was remarkable for its severity and speed, burning nearly $240 \mathrm{~km}^{2}$ in 
one day with stand-replacing intensity and covering $560 \mathrm{~km}^{2}$ within 3 weeks. The effects of wildfire on aquatic systems are highly variable, depending in part on the resistance and resilience of abiotic and biotic factors responsible for sediment transport and water movement through catchments. Streams affected by the fire contained higher concentrations of $\mathrm{NO}_{3}{ }^{-}$and $\mathrm{PO}_{4}{ }^{3-}$ within the first 2 years. Also, density and biomass of benthic macroinvertebrates were $60 \%-80 \%$ lower in fire-affected streams than in unburned streams. While fewer taxa were represented in year 1 , invertebrate community composition was similar to reference streams in year 2, suggesting that these streams will follow patterns of recovery observed in other forested ecosystems. The total invertebrate community $\mathrm{C}: \mathrm{N}$ ratio was negatively correlated with stream water $\mathrm{NO}_{3}{ }^{-}$concentration, possibly due to changes in community composition or alterations in limiting resources.

\section{ACKNOWLEDGMENTS}

This work was made possible by the dedication and enthusiasm of several undergraduate students at Colorado College, including Mitchell Crooks, Zheng Mi, Courtney Shannon, and Peter Erb. We thank the Natural Science Executive Committee, the Lindeman Foundation, and the Venture Grant Program at Colorado College for funding these excellent, motivated young scientists. Alexander Buyantuyev (ASU School of Life Sciences) generously assisted with the GIS database and maps, and we greatly appreciate the thoughtful comments on earlier versions of this manuscript provided by Drs. Ryan Sponseller, Stevan Earl, and Nancy Grimm. Field and lab assistance was provided by former Colorado College student Jean Ahrens and supported by a grant to S.J. Hall from the Andrew W. Mellon Foundation.

\section{Literature Cited}

Beche, L.A., S.L. Stephens, AND V.H. Resh. 2005. Effects of prescribed fire on a Sierra Nevada (California, USA) stream and its riparian zone. Forest Ecology and Management 218:37-59.

Boulton, A.J., G.L. Moss, and D. Smithyman. 2003. Short-term effects of aerially-applied fire suppressant foams on water chemistry and macroinvertebrates in streams after natural wild-fire on Kangaroo Island, South Australia. Hydrobiologia 498:177-189.

Chong, G., T. Stohlgren, C. Crosier, S. Simonson, G. Newman, and E. Petterson. 2003. Ecological effects of the Hayman Fire: part 7, key invasive nonnative plants. General Technical Report RMRS-GTR-114, USDA Forest Service, Rocky Mountain Research Station, Ogden, UT.

Cipra, J.E., E.F. Kelly, L. MacDonald, and J. Normanby. 2003. Ecological effects of the Hayman Fire: part 3, soil properties, erosion, and implications for rehabilitation and aquatic ecosystems. General Technical Report RMRS-GTR-114, USDA Forest Service, Rocky Mountain Research Station, Ogden, UT.

Covington, W.W., AND S.S. SACKetT. 1992. Soil mineral nitrogen changes following prescribed burning in ponderosa pine. Forest Ecology and Management 54:175-191.

Cross, W.F., J.P. Benstead, A.D. Rosemond, and J.B. WALLACE. 2003. Consumer-resource stoichiometry in detritus-based streams. Ecology Letters 6:721732 .

Daily, G.C., P.R. Ehrlich, and N.M. Haddad. 1993. Double keystone bird in a keystone species complex. Proceedings of the National Academy of Sciences of the United States of America 90:592-594.

EARL, S.R., AND D.W. BLINN. 2003. Effects of wildfire ash on water chemistry and biota in South-western U.S.A streams. Freshwater Biology 48:1015-1030.

ElliotT, K.J., AND J.M. Vose. 2005. Initial effects of prescribed fire on quality of soil solution and streamwater in the southern Appalachian Mountains. Southern Journal of Applied Forestry 29:5-15.

Frost, P.C., R.S. Stelzer, G.A. Lamberti, and J.J. Elser. 2002. Ecological stoichiometry of trophic interactions in the benthos: understanding the role of C:N:P ratios in lentic and lotic habitats. Journal of the North American Benthological Society 21:515-528.

Graham, R.T. 2003. Hayman Fire case study: summary. General Technical Report RMRS13 GTR-115, USDA Forest Service, Rocky Mountain Research Station, Ogden, UT.

Gresswell, R.E. 1999. Fire and aquatic ecosystems in forested biomes of North America. Transactions of the American Fisheries Society 128:193-221.

Grimm, N.B. 1988. Role of macroinvertebrates in nitrogen dynamics of a desert stream. Ecology 69:1884-1893.

Johnson, E.A., EDITOR. 2001. Forest fires: behavior and ecological effects. Academic Press, San Diego, CA.

Keeley, J.E., C.J. Fotheringham, and M. Morais. 1999. Reexamining fire suppression impacts on brushland fire regimes. Science 284:1829-1832.

Kershner, J.L., L. MacDonald, L.M. Decker, D. WinTERS, AND Z. LiBohova. 2003. Ecological effects of the Hayman Fire: fire-induced changes in aquatic ecosystems. General Technical Report RMRS-GTR114, USDA Forest Service, Rocky Mountain Research Station, Ogden, UT.

Kotliar, N.B., S. Simonson, G. Chong, and D. Theobald. 2003. Ecological effects of the Hayman Fire: part 8: effects on species of concern. USDA Forest Service, Rocky Mountain Research Station, Ogden, UT.

Lewis, S.A., J.Q. Wu, and P.R. Robichaud. 2006. Assessing burn severity and comparing soil water repellency, Hayman Fire, Colorado. Hydrological Processes 20: $1-16$.

Malmon, D.V., S.L. Reneau, D. Katzman, A. Lavine, and J. LyMAN. 2007. Suspended sediment transport in an ephemeral stream following wildfire. Journal of Geophysical Research - Earth Surface 112, F02006. doi:10.1029/2005JF000459. 
Minuc, T.B., And G.W. Minshall. 2005. The trophic basis of reference and post-fire stream food webs 10 years after wildfire in Yellowstone National Park. Aquatic Sciences 67:541-548.

MinshaLL, G.W. 2003. Responses of stream benthic macroinvertebrates to fire. Forest Ecology and Management 178:155-161.

Minshall, G.W., C.T. Robinson, D.E. Lawrence, D.A. ANDREWS, AND J.T. BRock. 2001a. Benthic macroinvertebrate assemblages in five central Idaho (USA) streams over a 10-year period following disturbance by wildfire. International Journal of Wildland Fire 10:201-213.

Minshall, G.W., T.V. Royer, and C.T. Robinson. 2001b. Response of the Cache Creek macroinvertebrates during the first 10 years following disturbance by the 1988 Yellowstone wildfires. Canadian Journal of Fisheries and Aquatic Science 58:1077-1088.

Naiman, R.J., and H. Decamps. 1997. The ecology of interfaces: riparian zones. Annual Review of Ecology and Systematics 28:621-658.

NPS-USGS. 2002. National Burn Severity Mapping Project: Hayman Fire of Pike-San Isabel Forest-2002. National Park Service-US Geological Survey, http:// burnseverity.cr.usgs.gov/show_fire.php?intID $=55$ "

Rinne, J.N. 1996. Short-term effects of wildfire on fishes and aquatic macroinvertebrates in the southwestern United States. North American Journal of Fisheries Management 16:653-658.

Robichaud, P., L. MacDonald, J. Freeouf, D. Neary, D. Martin, and L. Ashmun. 2003. Postfire rehabilitation of the Hayman Fire. General Technical Report RMRS-GTR-115, USDA Forest Service, Rocky Mountain Research Station, Ogden, UT.

Romme, W.H., C. Regan, M.R. Kaufmann, L. Huckaby, and T.T. Veblen. 2003a. Ecological effects of the Hayman Fire: part 4, forest succession. General Technical Report RMRS-GTR-114, USDA Forest Service, Rocky Mountain Research Station, Ogden, UT.

Romme, W.H., T.T. Veblen, M.R. Kaufmann, R. SherRIFF, AND C.M. REgan. 2003b. Ecological effects of the Hayman Fire: part 1, historical (pre-1860) and current (1860-2002) fire regimes. USDA Forest Service, Rocky Mountain Research Station, Ogden, UT.
Schoennagel, T., T.T. Veblen, and W.H. Romme. 2004. The interaction of fire, fuels, and climate across Rocky Mountain forests. BioScience 54:661-676.

Spencer, C.N., K.O. Gabel, and F.R. Hauer. 2003. Wildfire effects on stream food webs and nutrient dynamics in Glacier National Park, USA. Forest Ecology and Management 178:141-153.

SPSS. 2005. SPSS 11.0 for Macintosh. SPSS, Inc., Chicago, IL.

Stelzer, R.S., And G.A. Lamberti. 2002. Ecological stoichiometry in running waters: periphyton chemical composition and snail growth. Ecology 83:1039-1051.

Stephens, S.L., T. Meixner, M. Poth, B. McGurk, and D. PAYne. 2004. Prescribed fire, soils, and stream water chemistry in a watershed in the Lake Tahoe Basin, California. International Journal of Wildland Fire 13:27-35.

Sterner, R.W., and J.J. Elser. 2002. Ecological stoichiometry: the biology of elements from molecules to the biosphere. Princeton University Press, Princeton, NJ. 584 pp.

Veblen, T.T., T. Kitzberger, and J. Donnegan. 2000. Climatic and human influences on fire regimes in ponderosa pine forests in the Colorado Front Range. Ecological Applications 10:1178-1195.

Vila-Escale, M., T. Vegas-Vilarrubia, and N. Prat. 2007. Release of polycyclic aromatic compounds into a Mediterranean creek (Catalonia, NE Spain) after a forest fire. Water Research 41:2171-2179.

Westerling, A.L., H.G. Hidalgo, D.R. Cayan, and T.W. SWETNAM. 2006. Warming and earlier spring increase western US forest wildfire activity. Science 313 : 940-943.

Western Regional Climate Center. 2007. Western U.S. climate historical summaries: Cheesman, CO. Available from: http://www.wrcc.dri.edu/CLIMATEDATA.html

Wilson, M.A., And S.R. CARPEnTER. 1999. Economic valuation of freshwater ecosystem services in the United States: 1971-1997. Ecological Applications 9:772-783.

Received 22 August 2007 Accepted 6 May 2008 